\title{
Unesco text will target gene techniques
}

[WASHINGTON] A meeting of government experts held at the United Nations Educational, Scientific and Cultural Organization (Unesco) in Paris has modified a proposed declaration on genetics and human rights, due to be debated this autumn, so that it explicitly denounces human cloning and germline gene therapy.

The modification goes beyond the advice of Unesco's International Bioethics Committee (IBC), which has spent four years drafting the original declaration, and whose 53 members had broadly urged that the declaration should stick to general principles and not address specific technologies.

Most of the draft declaration was endorsed by the meeting with only minor changes. But the modification on cloning and germline gene therapy has raised concern in some quarters that it would put a novel restriction on particular types of research and medical intervention.

"Putting particular technologies into a document of this kind is a mistake," says Harold Edgar, IBC member and professor of law, science and technology at Columbia University in New York. He says such declarations should "espouse relatively few principles at relatively high levels of generality".

But the changes may not have gone far enough for some countries. Canada pulled out of last week's meeting, claiming in a statement that there had been "insufficient time to deal with unresolved articles and new substantive articles, such as human cloning and germline intervention". The Canadian delegation has come under pressure from aboriginal and disabled rights groups to take a strong stand on human rights.

The move to identify cloning and germline modifications as particular threats was led by delegates from Germany, and gained widespread support at the meeting, which was attended by experts from 83 countries.

"Anything that is not banned is allowed," declared Gerhard Fulda, Germany's ambassador to Unesco. "If we were to agree on a text which does not even mention a ban on cloning, we all know what the next day's headlines would be: 'Unesco: cloning still allowed'," he told the meeting. "In Germany, we could not justify that politically."

The draft now states that "practices which are contrary to human dignity, such as reproductive cloning of human beings, shall not be permitted". It identifies germline intervention as being potentially among such practices, and urges the IBC to point this out to Unesco's general conference when recommending how to implement the accord.
But Germany failed to gather sufficient support for a further change prohibiting human embryo research. Germany lost a similar battle in the Council of Europe last November, when that body adopted a Convention on Human Rights and Biomedicine allowing the use of human embryos for research, provided they are not created for such purposes (see Nature 384, 298; 1996.)

A Unesco press release quotes Noëlle Lenoir, a member of the French Constitutional Council and the president of the IBC, as saying that the declaration "does not aim to regulate, authorise or restrict specific scientific processes", but rather "to establish lasting ethical principles at a universal level".

Nevertheless, Lenoir calls the new draft "appropriate", as it indicates that cloning "raises great difficulties" with respect to the principles of the declaration. She says the rewording does not change an essential balance in the text between the protection of human rights and scientific freedom.

David Shapiro, recently retired executive secretary of the UK Nuffield Council on Bioethics, and an IBC member, suggests that, although the inclusion of the cloning phrase could be seen as "banner waving", if it "is the price of getting agreement, I think that's well worth paying". Meredith Wadman 